\title{
Pengaruh Kedisiplinan Dan Komunikasi Kerja Terhadap Kinerja Karyawan
}

\author{
Ella Anastasya Sinambela ${ }^{1}$, Yusuf Rahman Al Hakim ${ }^{2}$, Moch. Irfan ${ }^{3}$ \\ Universitas Mayjen Sungkono Mojokerto ${ }^{1,2,3}$
}

\begin{abstract}
Every company should try to develop the quality of human resources as the basic foundation for running the company's processes. In fact, only companies that pay attention to the quality of human resources can continue to survive business competition. The quality of human resources in the company is monitored through its behavior and job performance. One way to control employee behavior is through disciplinary programs. Besides that, it is also necessary to create a conducive working environment through good working communication among members of the organization. This study aims to analyze and discuss the effects of discipline and communication on job performance. The sampling technique uses non-probability sampling method with total sampling technique. The population in this study is the community, with a total sample of 93 respondents. The analysis tool used is multiple linear regression with the help of SPSS 24.0 for Windows software. The results of the study show that discipline and communication have a significant positive effect on job performance.
\end{abstract}

Keywords: discipline, communication, job performance

\section{Pendahuluan}

Persaingan yang semakin ketat menuntut setiap organisasi untuk senantiasa mawas diri dan atau berbenah diri dengan berbagai strategi untuk mendapatkan keunggulan bersaing. Strategi yang dapat dilakukan oleh suatu organisasi adalah mungkin dari dalam organisasi maupun dari dalam organisasi diantaranya adalah mengembangkan mutu sumber daya menusianya dan meningkatkan kualitas perusahaan dengan cara melakukan penilaian terhadap kinerja (job performance) yang dicapai oleh organisasi yang bersangkutan.

Usaha-usaha perusahaan untuk mengembangkan mutu sumber daya manusia dan meningkatkan kinerja karyawan biasanya dengan memberikan motivasi dan semangat kerja karyawan, meningkatan kedisiplinan dalam bekerja serta memperbaiki kualitas komunikasi kerja. Sering terjadi turnover karyawan di lingkungan perusahaan karena adanya faktor penawaran kompensasi yang sangat 
kompetitif serta banyak terjadi pembajakan tenaga kerja yang ditunjukkan oleh perusahaan - perusahaan baru terhadap para karyawan dari perusahaan yang lebih maju. Untuk mengantisipasi permasalahan ini, pihak perusahaan berusaha terus menjalin komunikasi yang efektif agar tetap terjalin hubungan baik dengan karyawan. Selain itu dengan upaya untuk mengembangkan kemampuan dan ketrampilan karyawan secara profesional merupakan wujud kepedulian perusahaan terhadap potensi dan pengembangan sumber daya manusia. Meski demikian hal tersebut perlu juga dikendalikan dengan upaya untuk menciptakan kedisiplinan yang nantinya dapat diharapkan dan meningkatkan karir sebagai perwujudan peningkatan kinerja karyawan.

Betapa pentingnya peranan karyawan dalam sebuah perusahaan. Oleh karena itu keberhasilan karyawan untuk mengembangkan kewajiban-kewajiban itu sangat tergantung dari kepentingan pribadi atau golongan terutama para karyawan dan pimpinan sehingga perlu sekali memiliki kedisiplinan untuk bekerja secara efektif dan efisien, sehingga tujuan dari perusahaan dapat tercapai.

Kedisiplinan karyawan harus terprogram dan berwujud sebagai tanggung jawab terhadap pekerjaannya dan tidak terlalu bersikap hati-hati tanpa rasa takut terhadap kesalahan yang mungkin berwujud sanksi dari atasannya. Dengan demikian kedisiplinan yang ditanamkan pimpinan pada karyawan harus menumbuhkan tanggung jawab terhadap pekerjaanya karena menyadari kewajiban dan mengutamakan hasil kerja dengan baik dan sesuai dengan standarat yang telah ditetapkan. Kedisiplinan adalah melakukan apa yang telah disetujui bersama para pemimpin dan pekerja yang persetujuan tertulis, lisan ataupun berupa peraturan atau kebiasaan. Kedisiplinan dapat merupakan suatu proses perkembangan dan instruksi baru setiap karyawan. Karena itu setiap pemimpin diharuskan menyisihkan waktu kerjanya untuk pengawasan pelaksanaan dalam kedisiplinan tersebut. Hal ini karena tindakan disiplin tidak hanya berkaitan langsung dengan sikap karyawan namun juga berpengaruh terhadap kinerja.

Tingkat kedisiplinan yang rendah akan berakibat pada ekonomi biaya tinggi yaitu terciptanya praktek kerja yang tidak efisien seperti mangkir kerja, kesengajaan untuk menghambat pekerjaan dan pelanggaran peraturan kerja yang lain. Tindakan 
pendisiplinan terhadap karyawan dapat dilakukan oleh manajemen melalui penciptaaan lingkungan kerja yang kondusif, yaitu lingkungan kerja yang tidak hanya mencakup lingkungan sosial antara karyawan didalamnya seperti hubungan sesama rekan kerja, hubungan antara pimpinan dan bawahan serta lingkungan psikografis yaitu lingkungan kejiwaan yang dihadapi karyawan. Oleh karena itu pihak manajemen harus memperhatikan dan berhati-hati untuk melakukan kebijakan-kebijakan yang berhubungan dengan kedisiplinan.

Untuk menciptakan perusahaan yang efektif, komunikasi adalah sarana penting untuk mengkoordinasi dan integrasi dari beraneka ragam fungsi keorganisasian misalnya pernyataan tentang kebijaksanaan perusahaan, instruksi, memo resmi, laporan antara bagian administrasi dan pemasaran serta informasi pedoman kerja dan pengumuman perusahaan. Hal ini karena kemampuan komunikasi karyawan yang ditingkatkan akan memberikan dampak pada pesanpesan dapat disampaikan dengan jelas dan akan terhindar dari kesalahpahaman yang mungkin terjadi selama bekerja. Sebaliknya bila kemampuan komunikasi karyawan sangat rendah dan berjalan tidak efektif akan dapat menimbulkan tekanan yang tidak perlu diantara para anggota perusahaan. Dengan meningkatnya kemampuan komunikasi karyawan baik horisantal maupun vertikal, terciptanya lingkungan kerja yang menyenangkan serta adanya perlakuan pimpinan yang baik dan menyenangkan yang dirasakan oleh karyawan, secara otomatis akan memotivasi karyawan untuk bekerja lebih giat. Kebaikan seperti ini akan mendukung citra perusahaan dalam masyarakat dan mengurangi keluar masuknya karyawan dalam perusahaan. Lebih jauh lagi rasa aman membantu mengurangi ketegangan diantara karyawan sehingga akan membantu peningkatan kinerja karyawan agar lebih optimal. Bila komunikasi dianggap aspek penting bagi peningkatan efektivitas organisasi dan iklim organisasi yang baik, maka secara logis perlu cara bagaimana menciptakan pertukaran informasi yang diperlukan dalam susunan organisasi. Dalam hal ini adalah bagaimana cara meningkatkan ketepatan, arus dan penerimaan komunikasi yang relevan sehingga tingkat ketidakpastian dapat ditekan serendah mungkin. Oleh karena itu dalam desain organisasi memberikan arus komunikasi dalam tiga arah, yaitu komunikasi ke atas, 
komunikasi kebawah dan komunikasi horisontal (Gunawan, 2015). Darmawan (2013) menyatakan bahwa komunikasi adalah suatu proses sosial yang mempunyai relevansi terluas di dalam memfungsikan setiap kelompok, organisasi atau masyarakat. Dalam rangka pengambilan keputusan serta pelaksanaan kegiatan pimpinan, baik berupa perencanaan, pengorganisasian, pendorongan dan pengendalian maka harus senantiasa dipelihara adanya komunikasi yang setepattepatnya (Atwater dan Waldman, 2008; Tourish, 2005)

Berdasarkan uraian sebelumnya penulis tertarik untuk melakukan penelitian di salah satu perusahaan yaitu PT. Eka Tjipta Persada Indonesia yang memiliki karyawan 107 karyawan termasuk jajaran pimpinan di setiap departemen dan devisi. Tujuan dari penelitian ini adalah untuk menganalisis dan mengetahui pengaruh variabel kedisiplinan dan komunikasi kerja secara parsial maupun secara simultan terhadap kinerja karyawan.

\section{Metode Penelitian}

Peneliti menggunakan jenis pendekatan analisis deskriptif kualitatif dengan penelitian survei. Respoden ditetapkan sebanyak 93 orang. Metode pengambilan sampel menggunakan metode total sampling. Pengujian dilakukan dengan menggunakan SPSS 24 for windows. Alat analisis yang digunakan adalah regresi linier berganda.

Ada tiga variabel yang terlibat di penelitian ini, yaitu variabel kedisiplinan, komunikasi kerja dan kinerja karyawan. Variabel terikat adalah kinerja karyawan (Y). Kinerja adalah merupakan hasil penilaian yang dilakukan oleh pimpinan terhadap aktivitas seorang karyawan yang memiliki kewajiban untuk menyelesaikan pekerjaannya. Adapun indikator variabel kinerja menurut Darmawan (2013) adalah (a). keterampilan teknis; (b) kemampuan menyelesaikan pekerjaan tepat waktu; (c) kemampuan karyawan dalam memahami permasalahan; (d) kemampuan untuk berkembang setelah menghadapi permasalahan; (e) kreativitas dalam bekerja.

Variabel bebas pertama adalah kedisiplinan (X1). Kedisiplinan adalah suatu sikap atau tingkah laku yang sesuai dengan aturan dari perusahaan baik yang tertulis maupun tidak tertulis. Kedisiplinan merupakan kebijakan tentang rasa tanggung 
jawab dan kewajiban bagi karyawan untuk mematuhi peraturan yang telah ditetapkan perusahaan tempat mereka bekerja. Indikator variabel disiplin menurut Mahyanalia (2016) adalah (a) tidak ada keterlambatan kerja; (b) kepatuhan; (c) berkurangnya terjadi kesalahan dan keteledoran; (d) tanggung jawab pekerjaan.

Variabel bebas kedua adalah komunikasi kerja (X2). Komunikasi kerja adalah hubungan dan interaksi antar individu berbentuk lisan maupun tulisan yang terjadi dalam organisasi dan terkait dengan pekerjaan. Adapun indikator variabel komunikasi menurut Gunawan (2015) adalah (a) hubungan yang baik antar karyawan atau terhadap pimpinan; (b) koordinasi dan kerja sama team; (c) tingkat persaingan kerja yang sehat.

Untuk desain kuesioner terdiri dari lima skala Likert dari pernyataan sangat setuju dengan nilai lima, setuju, ragu-ragu, tidak setuju dan sangat tidak setuju dengan nilai satu. Setelah diperoleh data akan dilakukan beberapa uji seperti uji validitas dan reliabilitas, uji asumsi klasik dan uji hipotesis.

Suatu instrumen dinyatakan valid bila instrumen ini dapatmengukur apa saja yang mau diukurnya serta menunjukkan apa yang ingin diungkapkan. Besarnya nilai $r$ dari setiap item pernyataan dilihat dari output SPSS di corrected items total correlation. Batasan validitas senilai 0.3. Bila korelasi lebih besar dari 0.3, pernyataan dinyatakan valid (Setiaji, 2004). Uji reliabilitas dilakukan terhadap item yang valid. Selanjutnya untuk uji reliabilitas data, dilihar melalui output SPSS pada nilai Cronbach Alpha yang lebih besar dari 0.6.

Uji asumsi klasik dilakukan dengan empat bentuk yaitu uji normalitas, uji heteroskedastisitas, uji multikolinearitas, dan uji autokorelasi. Dari uji asumsi klasik akan dilakukan uji $\mathrm{t}$ dan uji $\mathrm{F}$ sebagai alat untuk mengetahui pengaruh signifikan variabel bebas terhadap variabel terikat secara parsial maupun secara simultan.

\section{Hasil Dan Pembahasan}

Analisa hasil penelitian dimulai dengan memeriksa skala pengukuran. Pada penelitian ini digunakan analisis regresi melalui program SPSS 24. Pada metode analisis data ini, penulis mencoba menguraikan alat uji validitas dan reliabilitas, uji asumsi klasik, uji F, dan uji t. Berdasarkan hasil perhitungan dengan menggunakan 
SPSS diperoleh hasil seperti pada Tabel 1.

Tabel 1. Uji Reliabilitas

\begin{tabular}{cccc}
\hline Variabel & N of item & Cronbanch's Alpha & $\begin{array}{c}\text { Cut of } \\
\text { Value }\end{array}$ \\
\hline Kedisiplinan $(\mathbf{X 1})$ & 8 & 0.722 & 0.60 \\
\hline Komunikasi Kerja (X2) & 9 & 0.658 & 0.60 \\
\hline Kinerja Karyawan (Y) & 10 & 0.806 & 0.60 \\
\hline Surjanas
\end{tabular}

Sumber: output SPSS

Dari uji reliabilitas kedisiplinan (X1) dapat dilihat nilai cronbach's alpha sebesar 0.722 dimana delapan pernyataan dinyatakan valid. Dari uji reliabilitas komunikasi kerja (X2) dapat dilihat nilai cronbach's alpha sebesar 0.658 dengan sembilan pernyataan dinyatakan valid. Dari uji reliabilitas kinerja karyawan (Y) dapat dilihat nilai cronbach's alpha sebesar 0.806 dengan sepuluh pernyataan dinyatakan reliabel dan valid. Selanjutnya adalah pengujian hipotesis penelitian.

Setelah uji reliabilitas dan validitas dilakukan uji asumsi klasik. Uji yang pertama dilakukan adalah uji normalitas seperti ditunjukkan pada Gambar 1 berikut ini.

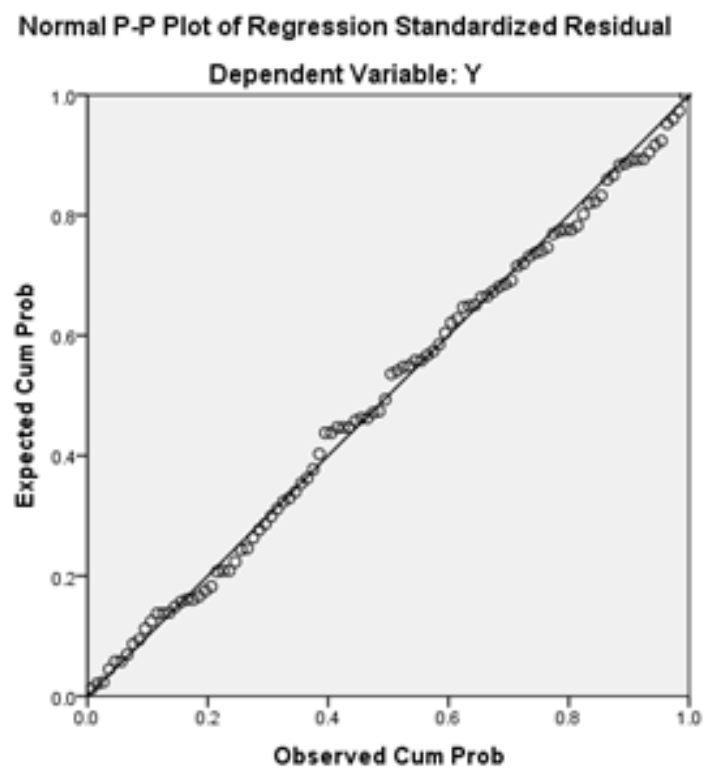

Gambar1 Normal Probability Plot Sumber: output SPSS

Gambar 1 menunjukkan bahwa titik-titik mengikuti garis diagonal. Distribusi normal akan membentuk suatu garis lurus diagonal dan ploting data akan 
dibandingkan dengan garis normal. Dengan demikian dapat dikatakan distribusi data adalah normal.

Uji asumsi klasik yang selanjutnya adalah uji autokorelasi. Untuk mendeteksi ada atau tidaknya korelasi ini dapat dilakukan dengan menggunakan uji Durbin Watson. Berdasarkan output SPSS menunjukkan tidak ada masalah autokorelasi karena nilai Durbin Watson menunjukkan angka 1.810 yang berarti berada di kisaran nilai 2 dan -2. Dengan demikian tidak ada masalah autokorelasi.

Uji selanjutnya adalah uji heteroskedastisitas. Gambar 2 menunjukkan bahwa titik-titik pada scatterplot tersebar dan berada pada masing-masing bagian di sumbu Y. Dengan demikian dapat disimpulkan bahwa tidak terjadi heteroskedastisitas

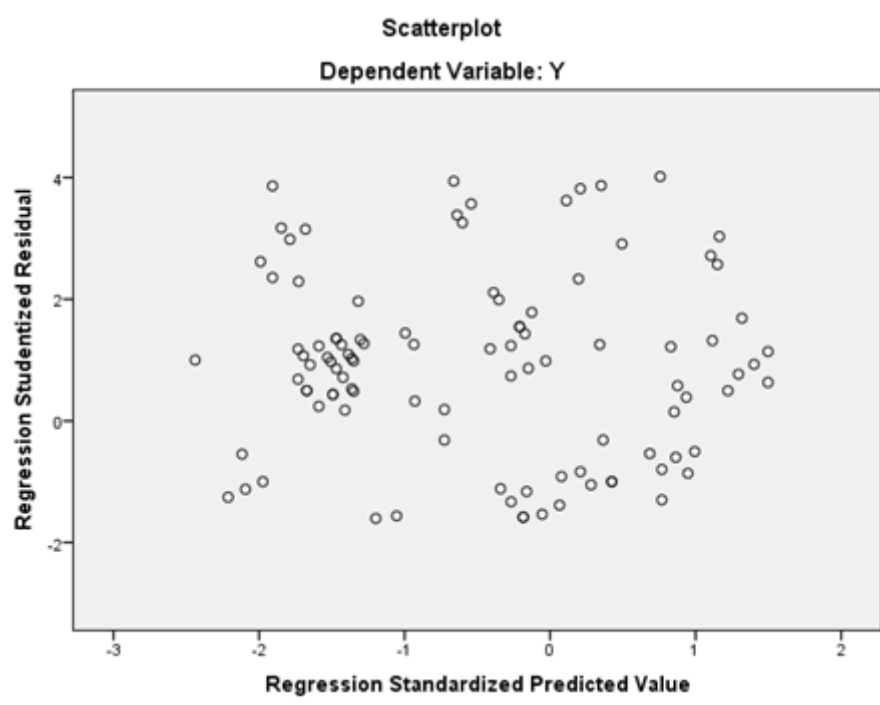

Gambar 2. Scatterplot Dependent Variable Sumber : Output SPSS

Uji multikolinieritas dilihat dari nilai tolerance dan nilai VIF. Nilai tolerance yang diperoleh kurang dari 1 dan VIF antara 1 dan 2 maka dapat dikatakan bahwa persamaan suatu model penelitian tidak menunjukkan gejala multikolinieritas. Adapun Nilai tolerance dan VIF yang diperoleh untuk model penelitian ini adalah seperti pada Tabel 3. Dari tabel itu dapat diketahui bahwa nilai nilai tolerance yang diperoleh kurang dari 1 VIF yang diperoleh untuk masingmasing variabel bebas antara 1 sampai 2, sehingga menunjukkan tidak adanya gejala multikolinieritas. 
Tabel 2 Collinearity Statistic

\begin{tabular}{ccc}
\hline Variabel & Tolerance & VIF \\
\hline $\mathrm{X}_{1}$ & 0,521 & 1,919 \\
$\mathrm{X}_{2}$ & 0,521 & 1,919 \\
\hline
\end{tabular}

Sumber: Output SPSS

Setelah empat bentuk dari uji asumsi klasik dilakukan maka selanjutnya dilakukan uji hipotesis melalui dua bentuk pengujian yaitu uji $\mathrm{F}$ dan uji t. Berdasarkan hasil perhitungan dengan menggunakan program SPSS diperoleh hasil seperti pada Tabel 3 berikut ini.

Tabel 3. Uji t

\begin{tabular}{|c|c|c|c|c|c|c|}
\hline \multirow{2}{*}{\multicolumn{2}{|c|}{ Model }} & \multicolumn{2}{|c|}{$\begin{array}{l}\text { Unstandardized } \\
\text { Coefficients }\end{array}$} & \multirow{2}{*}{$\begin{array}{c}\text { Standardized } \\
\text { Coefficients }\end{array}$} & \multirow[t]{2}{*}{$\mathrm{t}$} & \multirow[t]{2}{*}{ Sig. } \\
\hline & & B & $\begin{array}{l}\text { Std. } \\
\text { Error }\end{array}$ & & & \\
\hline \multirow[t]{3}{*}{1} & (Constant) & 1.730 & 1.171 & & 1.477 & .143 \\
\hline & $\mathrm{X} 1$ & .555 & .074 & .511 & 7.459 & .000 \\
\hline & $\mathrm{X} 2$ & .538 & .082 & .449 & 6.566 & .000 \\
\hline
\end{tabular}

Sumber: output SPSS

Dari Tabel 3 dapat dilihat kedua variabel bebas berpengaruh signifikan secara parsial terhadap variabel terikat. Dari hasil perhitungan Tabel 3 maka persamaan regresi yang diperoleh adalah

$$
\mathrm{Y}=1.730+0.555(\mathrm{X} 1)+0.538(\mathrm{X} 2)
$$

Hasil perhitungan Tabel 3 model persamaan regresi linier berganda sebelumnya menunjukkan bahwa adanya pengaruh dari variabel kedisiplinan (X1) dan komunikasi kerja (X2) sebagai variabel bebas terhadap kinerja karyawan (Y) sebagai variabel terikat. Dengan melakukan Uji t maka hipotesis yang menyatakan bahwa kedisiplinan dan komunikasi kerja berpengaruh signifikan secara parsial terhadap terhadap kinerja karyawan, dapat dibuktikan kebenarannya.

Tabel 4. Uji F

\begin{tabular}{|l|l|r|r|r|r|r|}
\hline \multicolumn{2}{|l|}{ Model } & \multicolumn{1}{|c|}{$\begin{array}{c}\text { Sum of } \\
\text { Squares }\end{array}$} & \multicolumn{1}{c|}{ df } & \multicolumn{1}{c|}{$\begin{array}{c}\text { Mean } \\
\text { Square }\end{array}$} & F & Sig. \\
\hline \multirow{2}{*}{1} & Regression & 183.498 & 2 & 91.749 & 159.766 & $.000^{\mathrm{a}}$ \\
\cline { 2 - 8 } & Residual & 51.684 & 90 & .574 & & \\
\cline { 2 - 8 } & Total & 235.183 & 92 & & & \\
\hline
\end{tabular}

Sumber: output SPSS 
Untuk mengetahui kebermaknaan dari pengaruh secara simultan variabel bebas terhadap variabel terikat digunakan uji F. Uji F ini dilakukan dari hasil perhitungan data pada Tabel 4 dapat dilihat bahwa nilai Fhitung sebesar 159.766 dengan probabilitas sebesar 0.000 , hal ini berarti bahwa pada taraf nyata $\alpha=0.05$ dapat dikatakan bahwa variabel kedisiplinan dan komunikasi kerja mempunyai pengaruh yang signifikan secara simultan terhadap terhadap kinerja karyawan.

Tabel 5 Model Summary

\begin{tabular}{lccccr}
\hline Model & $\mathrm{R}$ & $\begin{array}{c}\mathrm{R} \\
\text { Square }\end{array}$ & $\begin{array}{c}\text { Adjusted R } \\
\text { Square }\end{array}$ & $\begin{array}{c}\text { Std. Error of the } \\
\text { Estimate }\end{array}$ & Durbin-Watson \\
\hline 1 & $.883^{\mathrm{a}}$ & .780 & .775 & .75781 & 1.810 \\
\hline Sumber: output SPSS & & & &
\end{tabular}

Berdasarkan pada hasil penghitungan Tabel 5 koefisien $\mathrm{R}$ sebesar 0.883 menunjukkan adanya hubungan yang sangat kuat antara variabel bebas dengan variabel terikat. Koefisien determinan $\left(\mathrm{R}^{2}\right)$ sebesar 0.780 dan adjusted $\mathrm{R}$ squared sebesar 0.775 menunjukkan bahwa model regresi berganda ini yang variabel bebasnya terdiri dari kedisiplinan (X1) dan komunikasi kerja (X2) telah memberikan kontribusi sebesar $78 \%$ terhadap pembentukan variabel terikat yaitu kinerja karyawan sedangkan sisanya sebesar $8 \%$ ditentukan oleh variabel lain.

Hasil penelitian menyebutkan bahwa kedisiplinan berpengaruh signifikan terhadap kinerja karyawan. Temuan ini sesuai dengan temuan Darmawan (2015); Anthony (2017); Parashakti et al. (2018) dan Sardjana et al. (2018). Disiplin yang baik pada dasarnya akan tumbuh dan berasal dari hasil kesadaran manusia. Disiplin yang baik mencerminkan besarnya tanggung jawab seseorang untuk tugas-tugas yang diberikan kepadanya, ini mendorong tercapainya kinerja yang maksimal yang pada akhirnya membantu untuk mewujudkan realisasi tujuan organisasi. Secara umum, disiplin kerja dapat dilihat jika karyawan datang ke kantor secara teratur dan tepat waktu, berpakaian rapi di tempat kerja, menggunakan peralatan kantor dengan hati-hati, menghasilkan jumlah yang memuaskan dan kualitas kerja dengan mengikuti metode kerja yang ditentukan oleh perusahaan dan menyelesaikan pekerjaan baik dan memiliki semangat kerja yang tinggi (Webb et al., 2013).

Dari hasil penelitian menunjukkan bahwa komunikasi kerja berpengaruh 
signifikan terhadap kinerja karyawan. temuan ini sesuai dengan temuan dengan temuan Goris (2007) dan Triveni et al. (2007). Komunikasi sebagai perspektif utama untuk memahami bagaimana fungsi organisasi. Definisi awal organisasi difokuskan pada kelompok-kelompok individu yang bekerja bersama secara terkoordinasi dalam mengejar tujuan yang berkaitan dengan produksi. Komunikasi kemudian menjadi sarana utama dimana kegiatan individu dikoordinasikan untuk merancang, menyebarkan, dan mengejar tujuan organisasi (Gradner et al., 2001). Organisasi terbentuk dan berjalan melalui tindakan komunikasi antara anggota (Iedema dan Wodak, 1999). Meskipun pentingnya komunikasi dalam organisasi sudah mapan, masih ada kebutuhan untuk memeriksa langkah-langkah komunikasi organisasi yang berkaitan dengan konsep organisasi lainnya seperti kinerja karyawan. Minat muncul dari kenyataan bahwa kualitas kinerja pekerjaan dapat menentukan kualitas kehidupan organisasi dan efektivitas. Dalam organisasi, faktor dasar untuk peningkatan kinerja pekerjaan adalah komunikasi antara karyawan dan penyelia. Kedua individu harus dengan jelas memahami tugas dari posisi mereka masing-masing, dan karyawan harus mengetahui harapan atasan. Karyawan yang tertarik dengan peningkatan pekerjaan harus merasa bebas untuk berbicara dengan penyelia dan menerima bantuan atau saran mengenai kegiatan pengembangan pribadi dan profesional. Dengan demikian saat ini perusahaan tidak dapat eksis tanpa komunikasi yang efektif di antara anggotanya (Tourish, 2005). Komunikasi antar anggota untuk membuat dan mengembangkan kinerja yang lebih baik bagi kepentingan bersama.

\section{Kesimpulan}

Penelitian ini bertujuan untuk mengetahui pengaruh kedisiplinan dan komunikasi kerja secara simultan dan secara parsial terhadap kinerja karyawan. Dari hasil analisis data penelitian dan pembahasannya maka dalam beberapa hal dapat dijadikan kesimpulan seperti sebagai berikut : (a) komunikasi kerja berpengaruh signifikan terhadap kinerja karyawan; (b) kedisiplinan berpengaruh signifikan terhadap kinerja karyawan; (a) kedisiplinan dan komunikasi kerja berpengaruh signifikan secara simultan terhadap kinerja karyawan. Dari kesimpulan tersebut maka penulis akan memberikan beberapa saran yang berkaitan 
dengan hasil penelitian ini seperti sebagai berikut : (a) kinerja karyawan sangat dipengaruhi oleh adanya kedisiplinan yang berjalan dengan baik dalam suatu organisasi. Jika sistem organisasi berjalan baik diharapkan lebih mudah menegakkan kedisiplinan sehingga pekerjaan dapat terlaksana dengan baik dan berpengaruh terhadap peningkatan kinerja karyawan. Kedisiplinan yang baik mencermikan besarnya rasa tanggung jawab seseorang terhadap tugas-tugas yang diberikan kepadanya. Hal ini mendorong gairah kerja, semangat kerja karyawan dan terwujudnya tujuan organisasi.

Pimpinan harus memahami kompleksitas perilaku para karyawan untuk menerapkan peranan kepemimpinannya. Pentingnya komunikasi kerja bukan saja harus dilakukan oleh pemimpin tetapi komunikasi kerja juga harus diselaraskan terhadap sesama rekan kerja sehingga diharapkan akan tercipta lingkungan kerja yang harmonis, menekan konflik dan stres dalam kerja serta menumbuhkan semangat kerja. Komunikasi kerja yang bersifat positif yang terjadi antara karyawan akan mengarahkan kepada perilaku positif yang sangat berguna bagi pengembangan organisasi bila setiap karyawan diasumsikan memiliki etika baik dalam bekerja. Komunikasi yang baik akan menciptakan lingkungan kerja yang kondusif beserta kenyamanan kerja didalamnya.

\section{DAFTAR PUSTAKA}

Al Mehrzi, N., Singh, S.K. 2016. Competing through employee engagement: A proposed framework. International Journal of Productivity and Performance Management, 65(6), 831-843

Anthony, Apalia Ekakoron. 2017. Effects of Discipline Management on Employee Performance in an Organization: The Case of County Education Office Human Resource Department, Turkana Count International Academic Journal of Human Resource and Business Administration, 2(3): 1-18

Atwater, L. E., \& Waldman, D. 2008. Leadership, feedback, and the open communication gap. New York: Taylor \& Francis

Darmawan, Didit. 2013. Prinsip-Prinsip Perilaku Organisasi, Pena Semesta, Surabaya 
Darmawan, Didit. 2015. Peranan Motivasi Kerja, Kedisiplinan, dan Lingkungan Kerja terhadap Kinerja Guru SD di Kecamatan Gempol Kabupaten Pasuruan. Jurnal Ilmiah Manajemen Pendidikan Indonesia, Vol.1 No.3 Maret, 113-122

Goris, José R. 2007. Effects of satisfaction with communication on the relationship between individual-job congruence and job performance/satisfaction, Journal of Management Development, Vol. 26 Issue: 8, pp.737-752

Gradner J, Paulsen N, Gallois C, Callan V \& Monaghan P. 2001. An intergroup perspective on communication in organisations. In H Giles \& WP Robinson (eds.), The new handbook of language and social psychology (pp 561-584). Chichester, UK: Wiley.

Gunawan, Aditya. 2015. Perilaku Organisasi. Gramedia. Jakarta.

Hernaus, Tomislav and Josip Mikulić, 2013. "Work Characteristics and Work Performance of Knowledge Workers: What Goes Hand in Hand?," EFZG Working Papers Series 1309, Faculty of Economics and Business, University of Zagreb.

Iedema R \& Wodak R. 1999. Introduction: Organizational discourses and practices. Discourse and Society, 10:5-19.

Mahyanaila, Rahayu. 2016. Manajemen. Addar Press. Malang.

Mathis, Robert L ., Jackson, John H., 2006. Manajemen Sumber Daya Manusia, Edisi ke 10. Salemba Empat, Jakarta

Parashakti, Ryani D., Agustinus Haryadi, and Muhammad Nashar. 2018. Effect of Styles and Leadership Work Discipline to Employee Performance (Case Study of PT. Telecommunication Indonesia Tbk Dki Jakarta), ICOI-2018, Conference Paper, The 2018 International Conference of Organizational Innovation Volume 2018

Sardjana, Evie., Sudarmo Sudarmo, Didik G Suharto. 2018. The Effect of Remuneration, Work Discipline, Motivation on Performance, International Journal of Multicultural and Multireligious Understanding, Vol 5, No 6, $136-150$

Setiaji, Bambang. 2004. Panduan Riset Dengan Pendekatan Kuantitatif. Program 
Pascasarjana, Universitas Muhammadiyah Surakarta.

Sugiyono. 2017. Metodologi Penelitian Administrasi. Alfabeta. Bandung.

Tourish, D. 2005. Critical upward communication: Ten commandments for improving strategy and decision making. Long Range Planning, 38, 485503.

Triveni G, Rao BS \& Prasad A. 2007. Correlates of job performance of veterinary assistant surgeons. Journal of Research Contacts, 35:69-72.

Webb, J.W., Bruton, G.D., Tihanyi, L., Ireland, R.D. 2013. Research on entrepreneurship in the informal economy: Framing a research agenda. Journal of Business Venturing, 28(5), 598-614. 